Original Research Paper

\title{
Abundance and Distribution Patterns of Sea Urchins (Echinoidea) at Lakey Beach, Hu'u District, Dompu Regency
}

\author{
Fitriyani ${ }^{*}$, Didik Santoso ${ }^{1}$, Karnan $^{1}$ \\ ${ }^{1}$ Biology Education Study Program, Teacher Training and Education Faculty, University of \\ Mataram, Indonesia
}

\begin{abstract}
Article History
Received : December $12^{\text {th }}, 2021$

Revised : December 29 ${ }^{\text {th }}, 2021$

Accepted : January $18^{\text {th }}, 2022$

Published : January $27^{\text {th }}, 2022$

*Corresponding Author:

Fitriyani,

Biology Education Study

Program, Teacher Training and

Education Faculty, University

of Mataram, Indonesia;

Email: fitrify2012@gmail.com
\end{abstract}

\begin{abstract}
Sea urchins are marine biota that have many benefits for life, so there is a need for information about the existence of sea urchins. The existence of sea urchins in marine ecosystems has a significant influence on the ecological balance, one of which is for coral reefs, because sea urchins are one of the control of macroalgae populations. The purpose of this study was to determine the species abundance, diversity index, dominance index and distribution pattern of sea urchins (Echinoidea) at Lakey Beach, Hu'u District, Dompu Regency. This type of research is descriptive exploratory using purposive sampling method (chosen method) in determining the three research stations. The data obtained were analyzed using the species formula, the Shanon Wienner diversity index, the Simpson dominance index, and the Morisita index. The results showed that the highest species on the Lakey Coast were Echinometra mathei with values of $0.60 \mathrm{Ind} / \mathrm{m}^{2}$ and Echinometra viridis with values of $0.45 \mathrm{Ind} / \mathrm{m}^{2}$. The diversity index of sea urchins at Lakey Beach is included in the moderate criteria with a species diversity index value of $H^{\prime}=1.03$. The sea urchin dominance index in Lakey Beach is included in the low criteria with a species dominance index of 0.42. The distribution pattern of sea urchins on Lakey Beach includes two criteria, namely flocking and uniform. Types of sea urchins that belong to a grouped distribution pattern are Echinometra mathei and Echinometra viridis. While the types of sea urchins that have a uniform distribution pattern are Diadema setosum, Echinotrix calamaris (brown striped spines), Mespilia globulus, and Tripneustus gratilia. This research can be used as a reference and source of information to see the condition of the ecosystem in Lakey Beach, Hu'u District, Dompu Regency. So that the community and can preserve marine life such as sea urchins (Echinoidea) so that their lives can be maintained.
\end{abstract}

Keywords: abundance, distribution patterns, Sea urchins.

\section{Pendahuluan}

Bulu babi umumnya dikenal sebagai landak laut, dalam bahasa Inggris disebut Sea urchin dan dalam bahasa Jepang disebut uni. Bulu babi termasuk ke dalam phylum Echinodermata dalam kelas Echinoidea. Bulu babi merupakan pemakan alga yang hidup di terumbu karang sebagai sumber makanannya. Banyak spesies bulu babi pada di ekosistem terumbu karang, padan lamun atau substrat yang relatif keras umumnya dihuni oleh bulu babi. Untuk itulah bulu babi sering disebut sebagai herbivora (Noviana et al., 2019). Bulu babi memiliki peran dan manfaat dalam hal makanan, kesehatan, organisme model, dan organisme hias, baik secara ekologis maupun ekonomis. Dari sudut pandang ekologi, burung bulu babi berperan sebagai pengendali kehidupan laut sebagai salah satu spesies atau populasi makroalga yang penting, karena makroalga merupakan spesies yang pesaing atau kompetitif untuk ruang atau sumber makanan, pakan, terutama sinar matahari, untuk hewan karang. Keseimbangan populasi di permukaan laut akan menjaga keseimbangan populasi alga dan karang. Sementara kematian massal bulu babi berdampak pada hilangnya tutupan karang yang parah, hal itu dapat menyebabkan dominasi alga di karang (Firmandana et al., 2014). 
Bulu babi adalah makhluk laut yang memiliki banyak kepentingan hidup, sehingga penting untuk mengetahui keberadaannya, karena itulah banyak penelitian yang meneliti bulu babi. Bulu babi dan ekosistem karang dan lamun di perairan Sundak Yogyakarta. Irianto et al., (2016) Echinoidea di perairan pasang surut Pulau Liwutongki di Kabupaten Buton Selatan, Kecamatan Siompu. Lubis et al., (2017). Aulia et al., (2017) Struktur populasi Echinometra mataei di Pantai Mandalika, Lombok Tengah. Bulu babi (Echinoidea) merupakan salah satu sumber daya laut yang perlu dikembangkan dan dilindungi. Pantai Lakey merupakan salah satu pantai yang ada di Kecamatan Hu'u Kabupaten Dompu dan dijadikan sebagai objek wisata dalam dan luar negeri karena ombaknya besar, sehingga sering menjadi tempat diadakannya event kejuaraan selancar dari berbagai negara. Pantai Lakey, objek wisata yang populer di Kabupaten Dompu, karena mudahnya mengutamakan kondisi alam dan damai, serta berbagai aktivitas wisata seperti selancar, berenang, memancing, dan jenis wisata lainnya.

Karena status Pantai Lakey sebagai objek wisata dan adanya berbagai aktivitas tersebut akan mengurangi daya dukung lingkungan organisme laut, salah satunya bulu babi akan terganggu. Semakin terganggu lingkungan, semakin rendah jumlah bulu babi yang berkurang. Kami berharap penelitian ini dapat memberikan informasi mengenai jumlah dan penyebaran bulu babi (Echinoidea) di Pantai Lakey, Kecamatan Hu'u, Kabupaten Dompu. Untuk menjamin keberlangsungan populasi biota laut seperti bulu babi (echinoidea), menjamin kelangsungan hidupnya.

\section{Bahan dan Metode}

\section{Waktu dan tempat penelitian}

Penelitian dilaksanakan pada bulan Juni yaitu pada tanggal 7-14 Juni 2021 di Pantai Lakey Kecamatan Hu'u Kabupaten Dompu dengan memperhatikan surut terendah air laut. Surut terendah pada lokasi penelitian dapat dilihat dengan menggunakan aplikasi Tides. Gambaran lokasi penelitian dapat terlihat pada (Gambar 1).

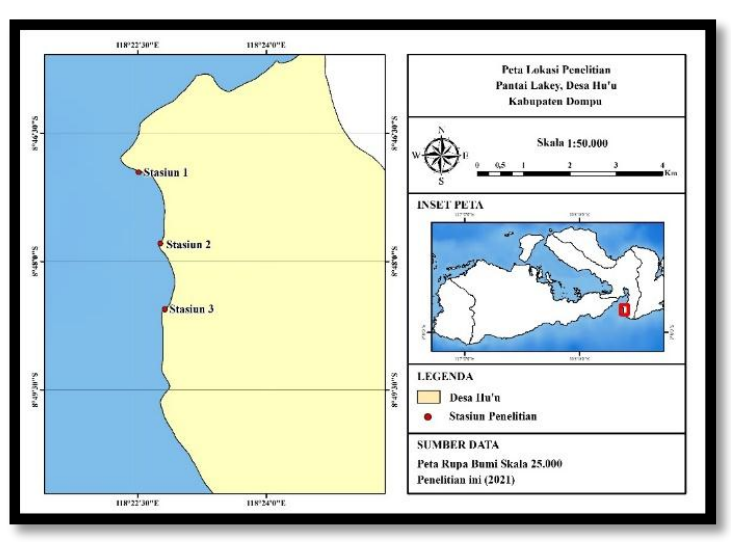

Gambar 1. Peta Lokasi Penelitian

\section{Alat dan bahan penelitian}

Alat yang digunakan dalam penelitian ini adalah roll meter $100 \mathrm{~m}$, patok kayu, GPS, kamera, tali rafia, pinset/capit, kuadrat $5 \times 1 \mathrm{~m}^{2}$, ember/wadah, refractometer. Thermometer, alat tulis. Sedangkan bahan yang digunakan kertas lakmus, sarung tangan.

\section{Pelaksanaa Penelitian}

Pengambilan sampel bulu babi dilakukan dengan metode transek kuadrat (Suharsono et al., 2014). Stasiun penelitian diidentifikasi menggunakan pendekatan yang ditargetkan, yaitu teknik pengambilan sampel berdasarkan pertimbangan tertentu (Fachrul, 2008). Ada beberapa hal yang menjadi pertimbangan, berdasarkan karakteristik wilayah setiap stasiun yang dapat mewakili populasi, seperti luas wilayah penelitian yaitu luas kawasan intertidal, karakteristik setiap kawasan, kemampuan peneliti, keamanan lokasi penelitian, dan ketersedian waktu dalam melakukan kegiatan penelitian ketika pengambilan data dilakukan (Katili, 2011). Sehingga penelitian ini dilakukan di 3 stasiun. Stasiun I dengan karakteristik wilayah yang jauh dari pemukiman warga, jarang ditemukan aktivitas wisata ataupun masyarakat. Stasiun II dengan karakteristik wilayah yang terdapat bangunan hotel dan menjadi pusat wisata di Pantai Lakey kemudian di stasiun III terdapat tenda-tenda yang dibangun oleh masyarakat setempat untuk menampung rumput laut, selain itu juga banyak aktivitas wisata atau masyarakat setempat.

Posisi atau titik stasiun ditentukan menggunakan aplikasi GPS (Global Positioning System) pada Handphone (HP). GPS merupakan sistem navigasi berbasis satelit yang berfungsi 
untuk menentukan posisi dipermukaan bumi dengan bantuan penyelaringan sinyal satelit. Posisi geografis stasiun penelitian dapat dilihat pada Tabel 1.

Tabel 1. Posisi geografis stasiun penelitian

\begin{tabular}{rc}
\hline $\begin{array}{c}\text { Nama } \\
\text { Stasiun }\end{array}$ & Posisi geografis \\
\hline Stasiun I & $\left(8^{\circ} 46^{\prime} 57,590^{\prime \prime} \mathrm{S} 118^{\circ} 22^{\prime} 30,688^{\prime \prime} \mathrm{E}\right)$ \\
Stasiun II & $\left(8^{\circ} 47^{\prime} 47,443^{\prime \prime} \mathrm{S} 118^{\circ} 22^{\prime} 45,840^{\prime \prime} \mathrm{E}\right)$ \\
stasiun III & $\left(8^{\circ} 48^{\prime} 33,419^{\prime \prime} \mathrm{S} 118^{\circ} 22^{\prime} 48,997^{\prime} \mathrm{E}\right)$ \\
\hline
\end{tabular}

Panjang garis transek yang digunakan dalam penelitian ini sangat bervariasi. Hal ini dikarenakan kawasan intertidal pasang surut di Pantai Lakey memiliki panjang wilayah pasang surut yang berbeda-beda. Kuadrat yang digunakan berukuran $5 \times 1 \mathrm{~m}^{2}$. Jumlah kuadrat pada stasiun I adalah 16 kuadrat, stasiun II 18 kuadrat dan stasiun III 20 kuadrat. Pengamatan dilakukan pada saat air laut surut terendah. Kemudian dilakukan pengumpulan data berupa pengamatan spesies bublu babi dan jumlah individu setiap spesies bulu babi pada kuadrat berukuran $5 \times \mathrm{x}^{2}$. bulu babi diidentifikasi langsung di lapangan dengan mengamati ciri morfologi bulu babi. Identifikasi ciri morfologi tikus ditentukan dengan pedoman identifikasi menurut Radjab (2011) Yusron (2010), serta jurnal pendukung. Pengambilan foto juga dilakukan di setiap stasiun untuk dokumentasi. Pengamatan parameter lingkungan dilakukan melalui pengamatan visual dan pengamatan langsung di lokasi penelitian.

\section{Analisis Data}

\section{Perhitungan kelimpahan}

Analisis kelimpahan spesies bulu babi menggunakan rumus (Zulham et al., 2018) sebagai berikut:

\section{$\mathbf{K i}=\mathbf{D i} / \mathbf{A}$}

Keterangan:

$\mathrm{Ki}=$ kelimpahan individu spesies ke-i (ind $\left./ \mathrm{m}^{2}\right)$

$\mathrm{Di}=$ Jumlah Individu Spesies ke-i (Individu)

$A=$ Luas Area $\left(\mathrm{m}^{2}\right)$

\section{Indeks Keanekaragaman (H')}

Indeks keanekaragaman menunjukkan kekayaan spesies dalam suatu komunitas dan menunjukkan keseimbangan jumlah individu spesies. Indeks keanekaragaman bulu babi dapat dihitung dengan menggunakan indeks keanekaragaman Shannon-Wiener (Fachrul, 2008).

$\mathbf{H}^{\prime}=-\Sigma$ Pi In Pi

Keterangan:

$\mathrm{H}^{\prime}=$ Keanekaragaman

$\mathrm{Pi}=\mathrm{ni} / \mathrm{N}$

$\mathrm{ni}=$ jumlah individu spesies ke-i

$\mathrm{N}=$ jumlah total individu

Tabel 2. Kriteria Indeks Keanekaragaman spesies bulu babi

\begin{tabular}{cc}
\hline Kriteria & Keanekaragaman \\
\hline Keanekaragaman Rendah & $\mathrm{H}^{\prime}<1$ \\
Keanekaragaman Sedang & $1<\mathrm{H}^{\prime}<3$ \\
Keanekaragaman Tinggi & $\mathrm{H}^{\prime}>3$ \\
\hline Sumber: (Rahma dan Fitriana, 2006)
\end{tabular}

\section{Indeks Dominansi (D)}

Nilai indeks dominansi dapat dihitung menggunakan indeks dominansi Simpson (Fachrul, 2008).

$\mathbf{D}=(\mathbf{n i} / \mathbf{N})^{2}$

Keterangan:

$\mathrm{D}=$ Dominansi

$\mathrm{ni}=$ Jumlah individu dari spesies ke- $\mathrm{i}$

$\mathrm{N}=$ Jumlah total spesies

Tabel 3. Kriteria Indeks Dominansi spesies Bulu babi

\begin{tabular}{cc}
\hline Kriteria & Dominansi \\
\hline Dominansi rendah & $0,00<\mathrm{D} \leq 0,50$ \\
Dominansi sedang & $0,50<\mathrm{D} \leq 0,75$ \\
Dominansi tinggi & $0,75<\mathrm{D} \leq 1,00$ \\
\hline Sumber: (Rahma dan Fitriana, 2006)
\end{tabular}

\section{Indeks Morisita (Pola Penyebaran)}

Sebaran Morisita (Khouw, 2009). Rumus untuk menghitung Indeks Sebaran Morisita sebagai berikut:

$$
I d=n \frac{\Sigma x^{2}-\Sigma x}{(\Sigma x)^{2}-\Sigma x}
$$

Keterangan:

$\mathrm{Id}=$ Indeks Sebaran Morisita

$\mathrm{n}=$ Jumlah kuadrat pengambilan contoh 
$\Sigma \mathrm{x}=$ Jumlah individu di setiap kuadrat $\mathrm{x} 1+\mathrm{x} 2+\ldots$

$\Sigma \times 2=$ Jumlah individu di setiap kuadrat di kuadratkan $=\mathrm{x} 12+\mathrm{x} 22+\ldots$.

Tabel 4. Kriteria Pola Distribusi

\begin{tabular}{ll}
\hline \multicolumn{1}{c}{ Kriteria } & (Id) \\
\hline Pola sebaran bersifat seragam & $\mathrm{Id}<1$ \\
Pola sebaran bersifat acak & $\mathrm{Id}=1$ \\
Pola sebaran bersifat mengelompok & $\mathrm{Id}>1$ \\
\hline
\end{tabular}

Sumber: (Khouw, 2009)

\section{Hasil dan Pembahasan}

\section{Kelimpahan Spesies}

Total individu dari 6 spesies dan 4 Famili yang ditemukan di Pantai Lakey adalah 700 individu. Spesies bulu babi yang ditemukan yaitu Diadema setosum, Echinometra viridis, Echinometra mathei, Echinotrix calamaris (Duri coklat belang), Tripneustes gratila, Mespilia globulus. Secara detail spesies bulu babi yang ditemukan di tiap lokasi penelitian seperti ditunjukkan pada Tabel 5.

Tabel 5. Kelimpahan Spesies

\begin{tabular}{|c|c|c|c|c|c|}
\hline \multirow[t]{2}{*}{ No. } & \multirow[t]{2}{*}{ Famili } & \multirow[t]{2}{*}{ Nama Spesies } & \multicolumn{3}{|c|}{ Stasiun penelitian } \\
\hline & & & I & II & III \\
\hline 1. & Diadematidae & Diadema setosum & $\checkmark$ & $\checkmark$ & $\checkmark$ \\
\hline 2. & Echinometridae & Echinometra viridis & $\checkmark$ & $\checkmark$ & $\checkmark$ \\
\hline 3. & Echinometridae & Echinometra mathei & $\checkmark$ & $\checkmark$ & $\checkmark$ \\
\hline 4. & Diadematidae & $\begin{array}{l}\text { Echinotrix calamaris } \\
\text { (Duri coklat belang) }\end{array}$ & & $\checkmark$ & - \\
\hline 5. & Toxopneustidae & Tripneustes gratila & - & - & $\checkmark$ \\
\hline 6. & Temnopleuridae & Mespilia globulus & - & - & $\checkmark$ \\
\hline & \multicolumn{2}{|c|}{ Jumlah Spsies } & 3 & 4 & 5 \\
\hline
\end{tabular}

Kelimpahan spesies bulu babi tertinggi di Pantai Lakey yaitu Echinometra matei dengan nilai kelimpahan $0,60 \mathrm{Ind} / \mathrm{m}^{2}$ dan Echinometra viridis dengan kelimpahan $0,45 \mathrm{Ind} / \mathrm{m}^{2}$. Sedangkan kelimpahan terendah di Pantai Lakey adalah Mespilia globulus dengan nilai kelimpahan $0,00 \mathrm{Ind} / \mathrm{m}^{2}$. kelimpahan spesies bulu babi dalam penelitian ini adalah Echinometra matei dengan nilai kelimpahan $1.667-1.86 \mathrm{Ind} / \mathrm{m}^{2}$ dan $1.800 \mathrm{ind} / \mathrm{m}^{2}$.

Kelimpahan spesies bulu babi di setiap stasiun merupakan yang tertinggi. Kelimpahan bulu babi tertinggi di stasiun I adalah 0,66
Ind $/ \mathrm{m}^{2}$, stasiun II adalah Echinometra matei dengan nilai kelimpahan $0,70 \mathrm{Ind} / \mathrm{m}^{2}$. Di Stasiun III, kelimpahan Echinometra viridis tertinggi adalah $0,49 \mathrm{Ind} / \mathrm{m}^{2}$. Sedangkan kelimpahan spesies di setiap stasiun paling rendah. Diadema setosum $0,09 \mathrm{Ind} / \mathrm{m}^{2}$, spesies terendah pada stasiun I, II spesies Echinotrix calamaris terendah (duri coklat belang) memiliki nilai kelimpahan 0,04 Ind/ $/ \mathrm{m}^{2}$, sedangkan di satsiun III, spesies terendah yaitu Mespilia globulus adalah $0,01 \mathrm{Ind} / \mathrm{m}^{2}$ (Lampiran 2). Nilai kelimpahan (Ind $/ \mathrm{m}^{2}$ ) bulu babi (Echinoidea) di Pantai Lakey ditunjukkan pada Gambar 2. 


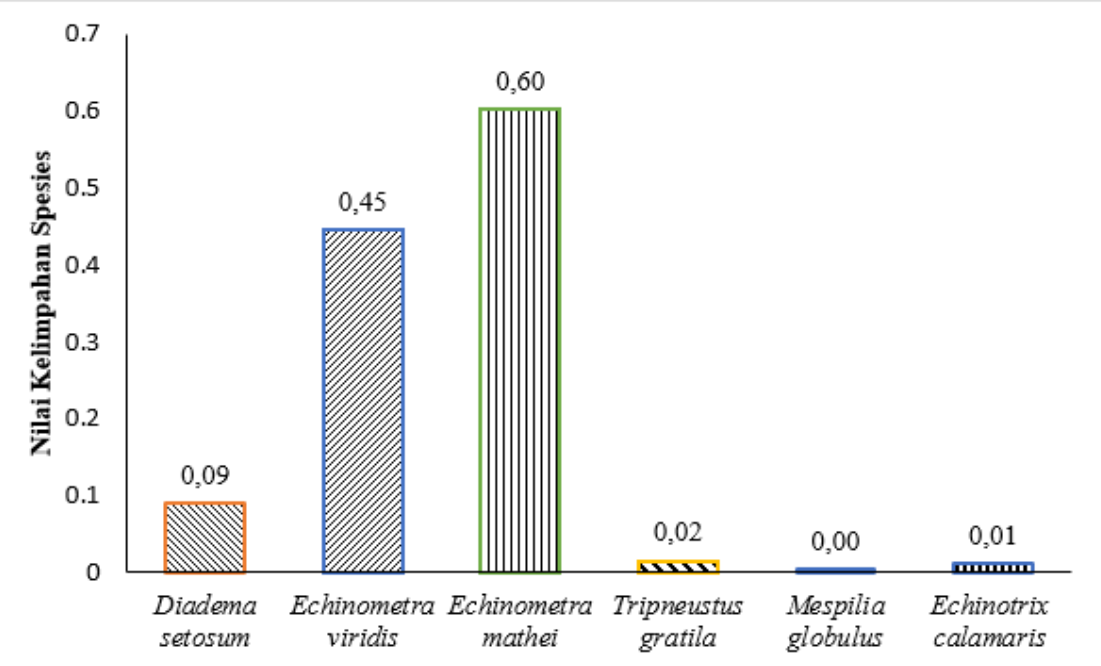

Gambar 2. Nilai Kelimpahan Spesies Bulu babi (Echinoidea) di Pantai Lakey

Bulu babi yang ditemukan di Pantai Lakey adalah Echinometra matei dan Echinometra viridis, dengan jumlah 628 individu dalam famili Echinometridae. Hasil penelitian ini serupa dengan penelitian terhadap 468 spesies termasuk 188 individu dari famili Echinometridae yang ditemukan di Pantai Jeding, Taman Nasional Bauran (Huda et al., 2017). Tingginya kelimpahan bulu babi spesies Echinometra matei dan Echinometra viridis diduga karena adanya jenis substrat di Pnatai Lakey yang menopang kehidupan bulu babi pada spesies ini yang terdiri dari pecahan karang, karang mati, pasir dan lamun cocok untuk kehidupan bulu babi spesies ini. Sesuai dengan pernyataan (Noviana et al., 2019) dengan judul penelitian Distribusi dan kelimpahan bulu babi (Echinoidea) di perairan pulau Pasir Putih, desa Sumberkima, Buleleng, Bali bahwa spesies Echinometra matei dan Echinometra viridis ini dapat hidup di daerah berpasir dan menjadikan lamun untuk makanan. Berdasarkan hasil pengamatan peneliti, Echinometra matei dan Echinometra viridis hidup dalam koloni, banyak di antaranya ditemukan di rongga karang mati dan terumbu karang, yang dibandingkan dengan padang lamun, yang bertujuan untuk melindungi diri dari pasang surut dan predator. Menurut Zakaria (2013), dalam penelitiannya yang berjudul Komunitas Landak Laut di Sukai dan Kepulauan Selatan, spesies Echinometra matei dapat ditemukan di semua perairan pesisir, terutama terumbu karang dan terumbu karang yang melimpah.
Hasil penelitian ini serupa dengan hasil penelitian Suryanti dan Ruswahyuni (2014), dimana spesies Echinometra matei pada substrat terumbu karang atau cerukan terumbu karang lebih tinggi dibandingkan pada substrat padang lamun di Perairan Karimunjawa Jepara. Hasil penelitian serupa lainnya, khususnya Satyawana et al (2014) di Perairan Pesisir Semerang, Lombok Timur, di mana pada substart terumbunya banyak ditemukan spesies Echinometra matei, lebih tinggi pada rataan karang, substrat berpasir dan lamun. Kelimpahan spesies Bulu babi yang terendah di Pantai Lakey adalah Diadema setosum, Echinotrix calamaris (duri coklat belang) dan Mespilia globulus. Zakaria (2013) melaporkan bahwa spesies Diadema setosum ditemukan pada berbagai substrat dan penyebarannya lebih banyak dibandingkan spesies bulu babi lainnya. Pernyataan ini sesuai dengan hasil penelitian bahwa Diadema setosum ditemukan di tiga stasiun di Pantai Lakey (Gambar 5). Rendahnya kelimpahan spesies Diadema setosum diyakini erat kaitannya dengan pariwisata/aktivitas masyarakat setempat seperti aktivitas Moti Kasi'i, memancing, berselancar dan aktivitas rekreasi lainnya. Dalam bahasa daerah Dompu, budaya masyarakat yang mengambil hasil laut pada saat air laut surut terendah disebut Moti Kasi'i. Berdasarkan hasil pengamatan peneliti, bahwa di Pantai Lakey pada saat air sururt pada titik terendahnya masyarakat berbondongbondomg untuk mengambil kerang-kerangan, biota laut lainnya (Moti Kasi'i). Namun spesies Diadema setosum banyak ditemukan mati atau 
dibunuh oleh masyarakat dan wisatawan karena dianggap berbahaya dan beracun.

Rendahnya kelimpahan spesies Echinotrix calamaris (duri coklat belang) disebabkan oleh ketidaksesuaian habitat, Echinotrix calamaris (duri coklat belang) umumnya mendiami daerah tubir dan lamun. Sesuai dengan pernyataan Mustaqim et al., (2013), spesies Echinotrix calamaris (duri coklat belang) banyak ditemukan di daerah tubir. Faktor lain yang mempengaruhi kelimpahan adalah predator. Predaor merupakan salah satu faktor yang paling mempengaruhi distribusi dan kelimpahan bulu babi. Spesies Echinotrix calamaris (duri coklat belang) hidup di terumbu karang dekat dengan daerah tubir dan bersembunyi di bawah cerukan karang untuk menghindari pemangsa (Lubis et al., 2016). Rendahbya kelimpahan Spesies Mespilia globulus kerna hanya ditemukan sedikit, hanya 2 individu dengan jenis substrat dasar berpasir yang ditemukan di Stasiun III. Keberadaan spesies Mespilia globulus yang hidup sendirisendiri atau terisolasi. Aziz (1994) dan Lubis et al (2014) bahwa bulu babi di padang lamun bisa hidup soliter atau menggelompok tergantung pada spesies dapat hidup sendiri-sendiri atau berkelompok, seperti Mespilia globulus,
Toxoneuptes pile, Pseudoboletia maculata, dan Echinotrix Diadema, tergantung pada spesies dan habitatnya. Berdasarkan hasil pengamatan peneliti di Pantai Lakey menunjukkan bahwa spesies Mespilia globulus dan Tripneutus gratilla, serta banyak sisa Tripneutus gratilla dan Mespilia globulus telah dikonsumsi (dibakar) oleh wisatawan. Diadema setosum mudah diambil dan tidak berbahaya seperti Echinotrix calamaris Echinotrix calamaris (duri coklat belang) dan spesies lainnya.

\section{Indeks Keanekaragaman Spesies ( $\left.\mathbf{H}^{\prime}\right)$}

Hasil perhitungan indeks keanekaragaman spesies menunjukkan bahwa bulu babi yang ditemukan di Pantai Lakey termasuk dalam kriteria sedang $\left(1<\mathrm{H}^{\prime}<3\right)$ dengan nilai indeks keanekaragaman $\mathrm{H}^{\prime}=1,03$ (Lampiran 3). Indeks keanekaragaman spesies di setiap stasiun. Pada Stasiun I nilai indeks keanekaragaman spesies bulu babi adalah $\mathrm{H}^{\prime}=0,90$. Pada Stasiun II nilai indeks keanekaragaman spesies bulu babi terutama nilai $\mathrm{H}^{\prime}=0,99$ termasuk dalam kriteria rendah. sedangkan pada stasiun III. Nilai indeks keanekaragaman bulu babi (Echinoidea) dapat dilihat pada Gambar 3.

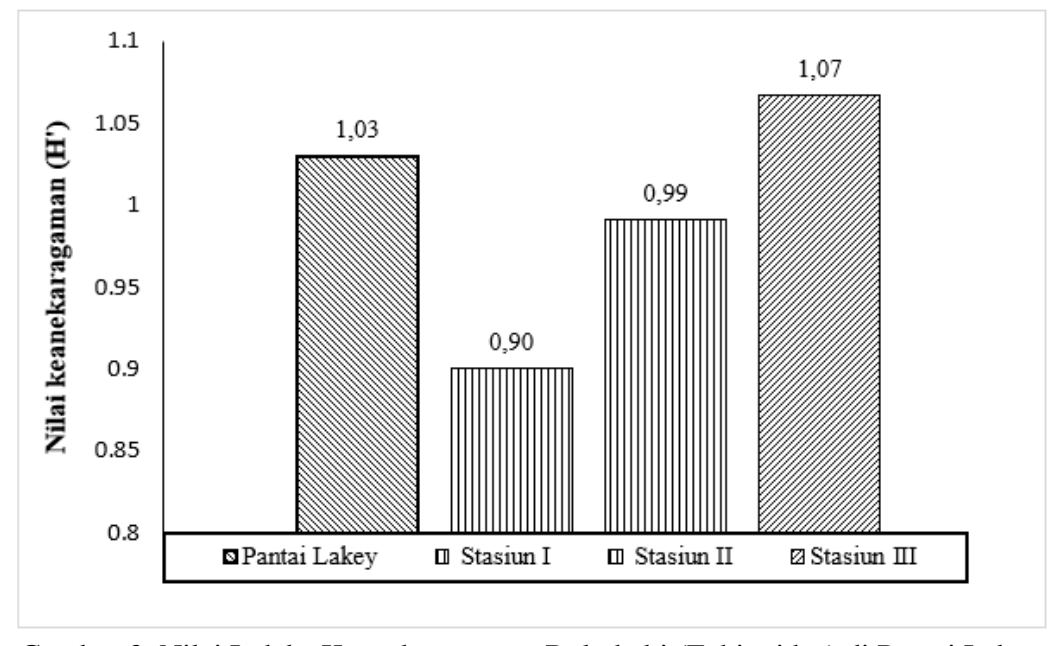

Gambar 3. Nilai Indeks Keanekaragaman Bulu babi (Echinoidea) di Pantai Lakey

Keanekaragaman spesies bulu babi yang ditemukan di Pantai Lakey termasuk dalam kriteria sedang dengan nilai indeks keanekaragaman jenis $\mathrm{H}^{\prime}=1,03$. Indeks keanekaragaman masing-masing stasiun untuk kriteria rendah, nilai indeks keanekaragaman dalam penelitian ini lebih tinggi dari indeks keanekaragaman (Irianto et al., 2016) yang diperoleh di perairan Pulau Liwutongkidi, Kecamatan Siompu, Kabupaten Buton Selatan, dan 0,71-0,77 dalam kriteria rendah. Untuk mendapatkan nilai indeks keanekaragaman. Untuk kriteria sedang, nilai indeks keanekaragaman yang diperoleh dari (Irianto et al., 2016) lebih tinggi dengan nilai 1,32 . 
Perbedaan nilai indeks keanekaragaman spesies pada masing-masing stasiun penelitian disebabkan karena adanya perbedaan jumlah spesies, jumlah individu tiap spesies dan jumlah total individu tiap spesies. Kurniawan et al., (2020) melaporkan bahwa semakin banyak spesies yang ditemukan maka semakin tinggi indeks keanekaragaman spesiesnya. Rendahnya keanekaragaman spesies dalam suatu komunitas dapat dipengaruhi oleh kelangkaan spesies, jumlah individu pada setiap spesies dan persebaran individu yang tidak merata, serta habitat yang tidak mendukung.

Perbedaan indeks keanekaragaman spesies yang diamati tergantung pada habitat dan kondisi lingkungan di Pantai Lakey. Peneliti Katili di Gorontalo (2011) menunjukkan bahwa keanekaragaman $\mathrm{H}<1$ yang kecil (rendah), hasil yang sangat rendah menunjukkan adanya tekanan ekologis pada ekosistem yang tidak stabil, $1<\mathrm{H}<3$ keanekaragaman sedang dan produktivitas cukup, kondisi ekologi yang relatif seimbang, dan keanekaragaman yang tinggi. cahaya dan ekosistem tekanan $\mathrm{H}>3$, keseimbangan ekologi yang stabil, produktivitas tinggi, toleransi terhadap tekanan ekologis. Ini berarti bahwa ada tekanan ekologis kecil di Pantai Lakey.

Tekanan ekologis ini dapat dikaitkan dengan aktivitas manusia di kawasan tersebut, aktivitas rekreasi/pariwisata, pemukiman dan transportasi perikanan. Berdasarkan hasil pengamatan penelitian di Pantai Lakey dan di pantai-pantai sekitar Pantai Lakey, pada saat air laut surut terendah, masyarakat dan wisatawan mengambil kerang dan biota laut, salah satunya bulu babi termasuk rumput laut (Moti Kasi'i). Kebutuhan ekonomi dengan benda tajam telah sengaja merusak, bahkan menghancurkan habitat bulu babi.

Pada stasiun III dengan jenis substrat pasir dan rumput laut, keanekaragaman spesies paling tinggi dari ketiga stasiun (kriteria sedang) karena kondisi substrat yang mendukung ketersediaan hara. Dibandingkan dengan stasiun I dan II, jenis substrat seperti pasir dan rumput laut yang dikenal sebagai sumber makanan bulu babi, sebagian besar terletak di III karena adanya jenis substratnya mendukung yaitu berpasir dan lamun menyediakan sumber makanan bagi bulu babi, tempat memijah. Sesuai dengan pernyataan Radjab (2003), ekosistem lamun termasuk ekosistem laut yang paling produktif. Supono dan Arbi (2010) dan Budiman (2014).

\section{Indeks Dominasi (D)}

Hasil perhitungan indeks dominasi spesies menunjukkan bahwa spesies bulu babi yang terdapat di Pantai Lakey termasuk dalam kriteria rendah dengan nilai indeks dominasi spesies $\mathrm{D}=$ 0,42 . Indeks dominasi spesies di setiap stasiun. Pada stasiun I indeks dominasi spesies $=0,44$, pada stasiun II indeks dominasi spesies $=0,44$ dan pada stasiun III indeks dominasi spesies = 0,40. Kategori menunjukkan sedikit dominasi oleh spesies. Nilai dominasi yang diperoleh dari (Noviana, et al., 2019) lebih rendah dari nilai dominasi yang diperoleh dalam penelitian ini, yaitu kriteria rendah $\mathrm{D}=0,37$. Nilai indeks dominasi bulu babi (Echinoidea) di Pantai Lakey dapat dilihat pada Gambar 4.

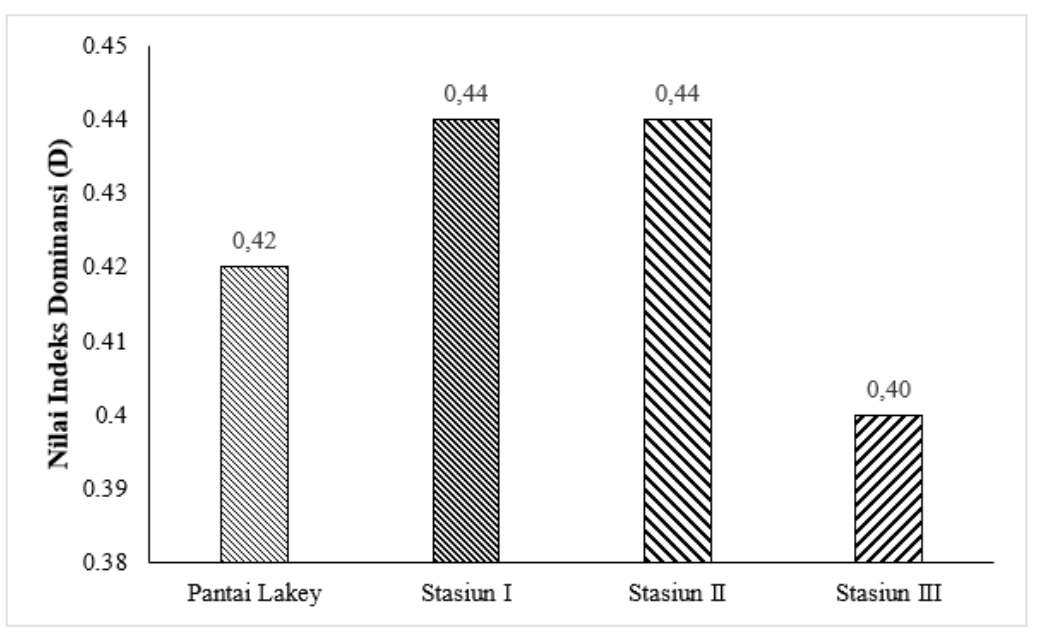

Gambar 4. Nilai indeks Dominansi Bulu babi (Echinoidea) di Pantai Lakey 
Indeks dominasi spesies bulu babi termasuk dalam kriteria rendah dengan indeks dominasi spesies sebesar 0,42 yang mendekati 0 (nol). Ini berarti tidak ada spesies bulu babi yang mendominasi di Pantai Lakey. Semakin tinggi nilai indeks keanekaragaman spesies, maka semakin rendah nilai indeks dominasi spesies, dan sebaliknya. Hal ini sesuai dengan pernyataan Indarjo et al (2004) dalam penelitiannya tentang keadaan terumbu karang di perairan Jepara, Pulau Panjang. Semarang mengemukakan bahwa jika nilai indeks dominasi spesies menurun, maka jumlah spesies yang mendominasi kawasan tersebut juga akan semakin sedikit di kawasan tersebut.

Tidak adanya spesies bulu babi yang mendominansi di pantai Lakey menunjukkan bahwa tidak ada persaingan di antara spesies lain karena sumber makanan bulu babi sudah tersedia dan merata. Tidak ada perusakan habitat yang serius yang dapat menyebabkan bulu babi berpindah saat mereka menetap di habitat baru. Dari data yang diperoleh terlihat jelas bahwa terdapat hubungan antara keanekaragaman jenis dengan dominasi spesies, dengan indeks keanekaragaman spesies tinggi atau sedang, indeks dominasi spesies rendah atau tidak ada spesies dominansi. Menurut Usman et al (2013), ekosistem dengan keanekaragaman spesies tinggi atau sedang berarti spesies dengan dominasi rendah.
Mempertimbangkan kriteria, hasilnya dihitung menggunakan (indeks Morisita). Spesies bulu babi yang termasuk dalam pola penyebaran (Id > 1) di Pantai Lakey, yaitu Echinometra matei dengan Id 14.3 dan Echinometra viridis dengan Id 7.84. Sedangkan di pantai Lakey, spesies bulu babi dengan pola penyebaran seragam $(\mathrm{Id}<1)$ adalah Diadema setosum dengan nilai Id 0,32, Echinotrix calamaris (duri coklat belang) dengan nilai Id 0 , 00, Tripneustus gratila dan nilai Id 0,01. Mespilia globulus dengan nilai Id 0, 00 .

Sedangkan pola penyebran mengelompok di setiap stasiun. Nilai indeks keanekaragaman (Id) Echinometra matei dengan Id $=4,46$ dan Echinometra viridis dengan Id $=2,47$ pada stasiun I. Spesies Echinometra matei pada Stasiun II memiliki nilai Id $=6,16$ dan spesies Echinometra viridis memiliki nilai $\mathrm{Id}=1,57$. Pada stasiun III nilai Id spesies Echinometra viridis sebesar 4,10 dan nilai Id spesies Echinometra matei sebesar 3,73. Sedangkan spesies bulu babi memiliki pola penyebaran yang seragam (Id < 1) pada nilai Id Diadema setosum dengan nilai Id 0,09, stasiun II Diadema setosum dengan nilai Id 0,13 dan Echinotrix calamaris (duri coklat belang) (terbakar) dengan nilai Id 0,01. Mespilia globulus stasiun III dengan nilai $\mathrm{Id}=0,00$, Tripneustus gratila dengan nilai Id 0,03 dan Diadema setosum dengan nilai Id 0,09. Nilai pola sebaran bulu babi (Echinoidea) di Pantai Lakey dapat dilihat pada Gambar 5.

\section{Pola Penyebaran}

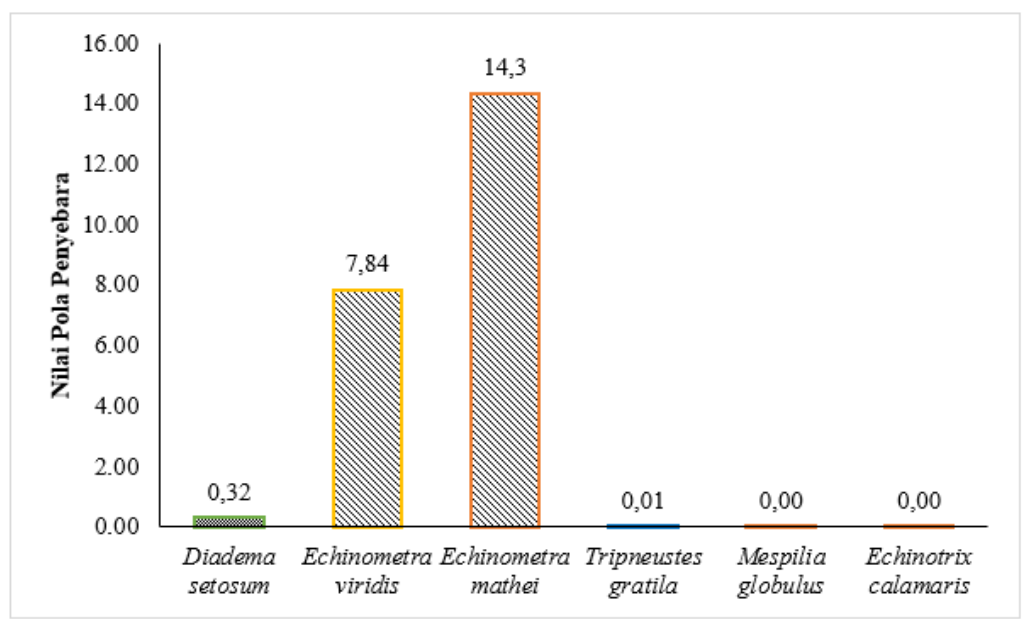

Gambar 5. Nilai Pola Penyebaran Spesies Bulu babi (Echinoidea) di Pantai Lakey 
Hasil penelitian menunjukkan bahwa penyebaran bulu babi di Pantai Lakey termasuk dalam kriteria seragam (Id < 1) dan mengelompok (Id > 1). Pola sebaran merupakan indikator interaksi keberadaan suatu populasi organisme di lingkungan yang ditandai dengan pola penyebaran yang berbeda akibat interaksi tersebut. Spesies bulu babi memiliki pola distribusi yang mengelompok, seperti Echinometra Mathei dan Echinometra Viridis, menunjukkan bahwa setiap stasiun memiliki kepadatan spesies bulu babi yang sama sebagai hasil dari koleksi individu.

Pola penyebaran mengelompok diguga karena jenis substrat, faktor lingkungan dan ketersediaan makanan di Pantai Lakey cocok untuk spesies bulu babi ini. Artinya Echinometra Mathei dan Echinometra Viridis dapat hidup di permukaan berpasir, lamun, terumbu karang dan karang mati. Hasil penelitian yang dilakukan pada spesies Echinometra Mathei dan Echinometra Viridis di Perairan Pasir Putih, Desa Sumberkima, Buleleng Bali (Noviana et al., 2019) mengelompokkan pola penyebaran di daerah berpasir dan berumput, bulu babi sebagai sumber makanan. Para peneliti Pantai Lakey menyimpulkan bahwa spesies Echinometra matei dan Echinometra viridis banyak ditemukan bersembunyi di substrat terumbu karang, cerukan terumbu karang mati, pecahan karang mati. Sesuai dengan pernyataan (Juliawan et al., 2017) dalam penelitiannya tentang kelimpahan dan pola sebaran bulu babi (Echinodea) di perairan Pulau Klah (Echinodea), pola penyebaran Echinometra Mathei dan Echinometra Viridis Sangat bergantung pada habitat dan faktor makanannya sering digunakan untuk melarikan diri dari pemangsa, mereka hidup sendiri di lubang atau terumbu karang mati.

Hasil penelitian ini sejalan dengan penelitian (Ferawati et al., 2014) pada komunitas lamun permukaan yang berbeda di perairan pesisir Permisan, Kabupaten Cilacap, di mana spesies bulu babi ditemukan lebih sedikit dibandingkan dengan substrat berpasir, terumbu karang, memungkinkan bulu babi untuk hidup dan bersembunyi sehingga mereka dapat melarikan diri dari pemangsa, sehingga penyebaran mengelompok lebih mungkin terjadi. Hasil penelitian yang sama melaporkan bahwa, di wilayah intertidal pantai Mandalika di pulau Lombok Indonesia (Bachtiar et al., 2020), terumbu karang berpasir yang ditutupi oleh spesies Echinometra Mathei tidak banyak ditemukan, sedangkan pada substrat karang sedang tidak banyak ditemukan pada terumbu berpasir atau rataan terumbu. Saat gelombang tinggi, banyak ditemukan Echinometra Mathei kebanjiran. Menurut Odum (1993), jika mengelompokkan pola penyebaran Echinometra Mathei dan Echinometra Viridis akan mempengaruhi reproduksi dan suplai makanannya. Hal ini disebabkan Pemisahan ke dalam kelompok memudahkan proses perkawinan dan mencari makan. Bentuk penyebaran ini juga merupakan bentuk perlindungan diri terhadap predator dan perubahan kondisi lingkungan.

Spesies bulu babi dengan pola penyebaran yang seragam adalah Diadema setosum, Echinotrix calamaris (duri coklat belang), Tripneustus gratila dan Mespilia globulus. Pola penyebaran yang seragam terjadi karena berbagai faktor antara lain faktor makanan, habitat, faktor lingkungan fisik dan kimia. Menurut Zakaria (2013), spesies Diademan Setosum adalah spesies yang hidup secara mandiri, tetapi beberapa spesies juga terjadi secara berkelompok di lokasi yang berbeda. Spesies Diademan Setosum dari Pantai Lakey memiliki distribusi yang seragam karena ketersediaan sumber makanan yang langka. Selain itu, spesies Diademan Setosum sering dibunuh oleh masyarakat atau wisatawan yang membeli rumput laut, remis (Moti Kasi'i) karena mereka menganggap bahwa duri Diademan Setosum berbahaya dan beracun sehingga menyebabkan spesies Diademan Setosum tidak ada lagi.

Spesies Echinotrix calamaris (duri coklat belang) jarang ditemukan di Pantai Lakey. Bulu babi spesies Echinotrix calamaris (duri coklat belang) memiliki pola distribusi yang seragam karena habitat dan makanannya. Sesuai dengan pernyataan De Beer (1990), sebaran lokal bulu babi sangat bergantung pada habitat dan faktor nutrisi. Spesies Echinotrix calamaris (duri coklat belang) hidup sendirian di terumbu karang untuk bersembunyi dari pemangsa. Menurut Mustaqim et al., (2013) yang menyatakan bahwa bulu babi dari spesies Echinotrix calamaris (duri coklat belang) dapat ditemukan di daerah rataan terumbu karang dan daerah pantai untuk bersembunyi dari predator. Hasil penelitian Lubis et al (2016) menunjukkan bahwa bulu babi 
Echinotrix calamaris (duri coklat belang) di daerah dengan terumbu karang, hamparan pasir dan lamun yang tumbuh berlebihan.

Spesies Tripneustus gratila dan Mespilia globulus di Pantai Lakey hanya ditemukan dalam jumlah kecil dan hanya di Stasiun III, di mana dasar berpasir ditutupi dengan lamun. Berdasarkan uraian Aziz (1994) dalam Noviana et al., (2019) bahwa semut pada umumnya memiliki habitat tertentu, seperti Tripneustus gratila, semut banyak ditemukan di daerah berpasir atau darah dan di daerah yang ditumbuhi lamun untuk makanan. sumber. Radjab (2004) juga menyatakan bahwa alur pada rumput laut Tripneustus gratila menyediakan lingkungan terbaik untuk pertumbuhan dan perlindungan. Namun, jumlah individu Tripneustus gratila yang terpengaruh oleh kegiatan masyarakat/pariwisata yang menggunakan bulu babi untuk dijual atau dikonsumsi relatif sedikit karena nilai ekonomisnya. Sedangkan Mespilia globulus karena memiliki kebiasaan tidak hidup berkelompok. Budiman dkk. (2014) Patech dkk. (2020), Mespilia globulus tidak ditemukan lebih sering secara berkelompok.

Adanya faktor fisika kimia yang berbeda sering ditunjukkan dengan penambahan banyak organisme atau berbeda. Suwignyo et al., (2005) dan (Padang et al., 2019) juga menjelaskan bahwa penyebaran berbagai spesies laut seperti bulu babi dan hewan lainnya disebabkan oleh kondisi lingkungan. Karena itulah bulu babi dapat hidup, tumbuh dan menyebar di perairan pesisir dan lingkungan yang mempengaruhinya. Pengukuran Faktor lingkungan fisik dan kimia di Pantai Lakey, meliputi suhu, salinitas, $\mathrm{pH}$, dan jenis substrat. Nilai faktor lingkungan yang diukur di Pantai Lakey disajikan pada Tabel 7.

Tabel 7. Faktor lingkungan yang diukur di Pantai Lakey

\begin{tabular}{ccccl}
\hline Stasiun & \multicolumn{4}{c}{ Faktor Lingkungan } \\
\cline { 2 - 5 } & Suhu ( $\left.{ }^{\circ} \mathrm{C}\right)$ & Salinitas (\%) & $\mathrm{pH}$ & \multicolumn{1}{c}{ Substrat } \\
\hline I & $30-31^{\circ} \mathrm{C}$ & $32-34$ & 8 & Berpasir, Karang mati dan sedikit lamun \\
II & $29-30^{\circ} \mathrm{C}$ & $34-35$ & 8 & Berpasir Pecahan karang dan karang mati \\
III & $30-31^{\circ} \mathrm{C}$ & $34-35$ & 8 & Berpasir dan Lamun \\
\hline
\end{tabular}

Suhu air di Pantai Lakey berkisar antara $29^{\circ} \mathrm{C}$ hingga $31^{\circ} \mathrm{C}$. Menurut Angreni (2017), suhu optimal untuk pertumbuhan bulu babi adalah antara $26^{\circ} \mathrm{C}-32^{\circ} \mathrm{C}$. Berdasarkan penjelasan tersebut dapat disimpulkan bahwa kisaran suhu yang diperoleh di Pantai Lakey juga dapat mendukung kehidupan bulu babi. Salinitas Pantai Lakey berkisar antara 32-35\%. Zakaria (2013) menambahkan bahwa salinitas 34-35\% masih cocok untuk biota laut (Echinoidea). Berdasarkan penjelasan tersebut dapat disimpulkan bahwa nilai salinitas yang diperoleh di Pantai Lakey juga dapat menunjang kehidupan bulu babi.

PH atau keasaman air di Pantai Lakey adalah sama, sehingga 8. Zakaria (2013) menyatakan bahwa $\mathrm{pH}$ 7,0-8,5 merupakan toleransi yang baik untuk bulu babi. Berdasarkan pernyataan tersebut, dapat disimpulkan bahwa kisaran $\mathrm{pH}$ yang diperoleh di Pantai Lakey juga dapat mendukung kehidupan bulu babi. Substrat di Pantai Lakey. Substrat di Stasiun I adalah pasir, karang mati dan beberapa lamun, II.
Stasiun adalah pasir, karang sisa, karang mati dan III. stasiun adalah pasir dan rumput laut. Menurut Suryanti dan Ruswahyuni (2014:66), bulu babi (Echinoidea) banyak dijumpai di habitat terumbu datar, gundukan pasir berbatu, batupasir, dan padang lamun. Budiman et al (2014) melaporkan kepadatan bulu babi yang tinggi di kawasan terumbu karang. Berdasarkan pernyataan tersebut, dapat disimpulkan bahwa substrat di Pantai Lakey dapat mendukung kehidupan bulu babi.

\section{Kesimpulan}

Berdasarkan hasil penelitian, dapat ditarik beberapa kesimpulan: 1) Kekayaan spesies danau tertinggi di Pantai Lakey adalah Echinometra matei sebesar $0,60 \mathrm{Ind} / \mathrm{m}^{2}$ dan Echinometra viridis sebesar $0,45 \mathrm{Ind} / \mathrm{m}^{2}$. 2) Indeks keanekaragaman bulu babi Pantai Lakey termasuk sedang, dengan nilai indeks keanekaragaman $\mathrm{H}^{\prime}=1,03$. 3) Indeks dominasi bulu babi di Pantai Lakey termasuk dalam 
kriteria rendah dengan nilai indeks dominasi spesies $\mathrm{D}=0,42$, sehingga dapat diketahui bahwa tidak ada spesies bulu babi yang dominan di Pantai Lakey. 4) Peta sebaran bulu babi di Pantai Lakey termasuk kriteria mengelompok dan kriteria seragam. Spesies bulu babi yang termasuk dalam pola penyebaran mengelompok di Pantai Lakey adalah Echinometra matei dan Echinometra viridis. Sedangkan spesies bulu babi dengan poka penyebaran seragam di Pantai Lakey adalah Diadema setosum, Echinotrix calamaris (duri coklat belang), Mespilia globulus dan Tripneustus gratila.

\section{Ucapan Terima Kasih}

Terima kasih kami sampaikan kepada semua pihak yang telah membantu dalam proses pelaksanaan dan penyelesaian kegiatan Penelitian ini.

\section{Referensi}

Alwi, D., Muhammad, S. H., \& Tae, I. (2020). Karakteristik Morfologi dan Indeks Ekologi Bulu Babi (Echinoidea) di Perairan Desa Wawama Kabupaten Pulau Morotai. Jurnal Sumberdaya Akuatik Indopasifik. 4(1):23.

Aulia, B.W., I. Bachtiar, \& Jamaluddin (2017). Kelimpahan dan Struktur Populasi Echinometra Mathaei (Class Echinoidea) di Kawasan Intertidal Pantai Mandalika Lombok Tengah Sebagai Sumber Belajar Biologi. Prosiding Seminar Nasional Pendidikan Biologi. ISBN: 978602-61265-2-8: 602-610.

Bachtiar, I., W. I. Merta, Kusmiyati, \& AR, Syachruddin (2020). Komunitas Echinodermata di kawasan intertidal Pantai Mandalika Pulau Lombok, Indonesia. Jurnal Ilmu-Ilmu Perairan, Pesisir dan Perikanan. 9(2): 156-163.

Budiman, C.C., Katili, D.Y., Langoy, M.L.D, \& Maabat, P.V. (2014). Keanekaragaman Echinodermata di Pantai Basaan Satu Kecematan Ratototok Sulawesi Utara. Jurnal FMIPA Unsrat. 3(2): 97-101.

Fachrul MF. (2008). Metode Sampling Bioekologi. Bumi Aksara. Jakarta.

Ferawati, E., D. S. Widyartini \& I, Insan (2014). Studi Komunitas Rumput Laut Pada
Berbagai Substrat di Perairan Pantai Permisan Kabupaten Cilacap. Scripta Biologica. 1(1):55-60.

Firmandana, T. C., Suryanti, \& Ruswahyuni (2014). Kelimpahan Bulu Babi (Sea Urchin) pada Ekosistem Karang dan Lamun di Perairan Pantai Sundak, Yogyakarta. Jurnal Maquares. 3(4):41-50.

Huda, I., M. A., Sudarmadji, S., \& Fajariyah, S. (2017). Keanekaragaman Jenis Echinoidea di Zona Intertidal Pantai Jeding Taman Nasional Baluran. Berkala Sainstek. 5(2): 61.

Indarjo, Agus, Wisnu, WI, \& M. Munasik (2004). Kondisi Terumbu Karang di Perairan Pulau Panjang Jepara. Semarang: Universitas Diponegoro. Jurnal Ilmu Kelautan. 9 (4): 217 - 224.

Irianto, A., Jahidin, J. \& Hittah,W.S. (2016). Kelimpahan Bulu Babi (Echinoidea) di Intertidal Perairan Pulau Liwutongkidi Kecamatan Siompu Kabupaten Buton Selatan. Jurnal Ampibi. 1(2): 27-30.

Juliawan, Dewiyanti, I., \& Nurfadillah (2017). Kelimpahan dan Pola Sebaran Bulu Babi ( Echinodea ) di Perairan Pulau Klah Kota Sabang The Abundance and Distribution Pattern of Sea Urchin (Echinodea ) in The Water of The Island Klah of Sabang City. Jurnal Ilmiah Mahasiswa Kelautan Dan Perikanan Unsyiah. 2(4): 541-546.

Katili, A. S. (2011). Struktur komunitas echinodermata pada zona intertidal di gorontalo. Jurnal Penelitian Dan Pendidikan. 8(1): 51-61.

Khouw, A.S. (2009). Metode dan Analisa Kuantitatif Dalam Bioekologi Laut. Jakarta, Indonesia: Pusat Pembelajaran dan Pengembangan Pesisir dan Laut (P4L), Direktorat Jenderal Kelautan, Pesisir dan Pulau-Pulau Kecil (KP3K).Departemen Kelautan dan Perikanan.

Lubis, S.A., Arief, A.P., \& Rofiza, Y. (2016). Spesies Bulu Babi (Echinoidea) di Perairan Pulau Panjang Kabupaten Bangka Tengah Provinsi Bangka Belitung. Jurnal Pendidikan Biologi Fakultas Keguruan Dan Ilmu Pendidikan Universitas Pasir Pengaraian. 1-6.

Mustaqim, M., Ruswahyuni \& Suryanti (2013). Kelimpahan Jenis Bulu Babi (Echinoidea, leske 1778) di Daratan dan Tubir Terumbu 
Karang di Perairan Sijago-Jago, Tapanuli Tengah. Jurnal of Marques. 2 (4): 61-70.

Noviana Putu, N., , E., Gde, P., Julyantoro, S., Ayu, D., \& Pebriani, A. (2019). Distribusi dan Kelimpahan Bulu Babi ( Echinoidea) Di. Current Trends in Aquatic Science. 2(1): 22-29.

Odum, E .P. (1993). Dasar-dasar Ekologi. Yogyakarta: Gajah Mada University Press.

Padang, A., Nurlina, N., Tuasikal, T., \& Subiyanto, R. (2019). Kandungan Gizi Bulu Babi (Echinoidea). Agrikan: Jurnal Agribisnis Perikanan. 12(2): 220.

Patech, L. R., Abdul Syukur., \& Didik Santoso (2020). Kelimpahan dan Keanekragaman Spesies Echinodermata sebagai Indikator Fungsi Ekologi Lamun di Perairan Pesisir Lombok Timur. Jurnal Sains Teknologi dan Lingkungan. 6(1): 40-49.

Radjab, A.W. (2011). Reproduksi dan Siklus Hidup Sea Urchin. Jurnal Oseana. XXVI (3). Jakarta: Pusat Penelitian OseanografiLIPI.

Satyawan, N.M., Wardiatno,Y., \& Kurnia, R. (2014). Keanekaragaman Spesies dan Zonasi Habitat Echinodermata di Perairan Pantai Semerang, Lombok Timur. Jurnal Biologi Tropis, 14 (2): 85-88.

Somma, A., Zahida, F., \& Yuda, P. (2017). Kelimpahan dan Pola Penyebaran Bulu Babi ( Echinoidea ) di Terumbu Pendahuluan Metode Penelitian. Biota. 2(3): 111-115.

Suharsono, K., \& Sumadhiharga, O.K. (2014). Panduan Monitoring Kesehatan terumbu karang. Coremap-CTI-LIPI: Jakarta.

Supono \& U.Y. Arbi. (2010). Jenis-jenis Ekinodermata di Padang Lamun Perairan Kema, Sulawesi Utara. Oseanologi dan Limnologi di Indonesia. 36(3): 329-341.

Supono, Ucu, Y.A. (2012). Kelimpahan dan Keanekaragaman Echinodermata di Pulau Pari Kepulauan Seribu. Jurnal Ilmu dan Teknologi Kelautan Tropis. 4 (1): 114120.

Suryanti \& Ruswahyuni (2014). Perbedaan Kelimpahan Bulu Babi (Echinoidea) pada Ekosistem Karang dan Lamun di Pancuran Belakang, Karimunjawa Jepara. Jurnal Saintek Perikanan. 10(1):62-67.
Zakaria IJ. (2013). Komunitas Bulu Babi (Echinoidea) di Pulau Sukai dan Pulau Selatan Sumatera Barat. Prosiding Semirata FMIPA Universitas Lampung. 381-387.

Zulham, Nanda, Jaka., Ita Karlina, \& Chandra Joei Koenawan (2018). Hubungan Kerapatan Lamun terhadap Kalimpahan Bivalvia di Perairan Desa Teluk Bakau Kabupaten Bintan. Universitas Maritim Ali Haji. 